\title{
Culture and Language as Factors Related in the Process of Learning and Education
}

Irena Papa

University of Tirana

irenasevdaraj@yahoo.com

\begin{abstract}
Communicative language teaching has become a familiar part of the landscape of language teaching in the last three or four decades. Teachers who perceive the objectives of teaching foreign languages associated with learning intercultural competence will be more inclined to make the process of teaching foreign languages more intercultural than teachers who perceive objectives as related to the acquisition of communicative competence. In this paper the relationship between culture and language is going to be explored by focusing on their role and impact in the process of learning languages and education.
\end{abstract}

Keywords: culture, language, communicative competence, education, "teaching culture and language", "the relationship between culture and language"

\section{Introduction}

While we try to teach students of other nationalities our language, or when we try to teach Albanian students a foreign language, or an international language, such as English, we should not underestimate the value of their mother tongue and the values of their culture. We should be cautious when speaking about a culture and a country in order not to make students feel as if their cultures are being undervalued, and thus making them feel uncomfortable and discriminated against especially when teaching Albanian to students from other countries.

The relationship between language and culture is very important and delicate. Schools in countries where the number of foreign students is high are in constant search for ways and methods to incorporate teaching methods and materials which can ease the acquisition of the native language by speakers of other languages. As teachers of foreign languages we should admit that language and culture are inseparable. According to Wei, language has a dual character: both as a means of communication and a carrier of culture. Language without culture is unthinkable, so is human culture without language. A particular language is a mirror of a particular culture. ${ }^{1}$ They contribute not only in the development of personality, but also in the way an individual or a society interprets reality.

Brown describes the relation between language and culture as follows: "A language is a part of a culture and a culture is a part of a language; the two are intricately interwoven so that one cannot separate the two without losing the significance of either language or culture". ${ }^{2}$ Whilst $\mathrm{GaO}^{3}$ argues that, the interdependence of language learning and cultural learning is so evident that one can conclude that language learning is culture learning and consequently, language teaching is cultural teaching. He further states that foreign language teachers should be aware of the place of cultural studies in foreign language classroom and attempt to enhance students' cultural awareness and improve their communication competence.

Language is the most evident way of expressing a culture, and the major part of teaching and learning, either in a class or at home, is made by means of language.

\footnotetext{
1 Wei, Y. Integrating Chinese Culture with TEFL in Chinese Classroom. Sino-US English Teaching, 2(7), 2005, 56.

2 Brown, H. D. Principles of language learning and teaching, 1994, 165.

${ }^{3} \mathrm{Gao}, \mathrm{F}$. Language is Culture - On Intercultural Communication, Journal of Language and Linguistics, 5(1), $2006,59$.
} 


\section{What is Culture?}

Culture is a key element to communication, especially to the intercultural one. It is so inherent and innate that we are often not aware of it and don't even think about it. We consider culture as an integral part of our life and customs. Trying to understand someone else's culture is similar to explaining to a fish that it lives in water. ${ }^{1}$

Culture and language distinguish one nation from another. They are often seen as closely related and sometimes inseparable from one another and are often treated by people as being equivalent, wrongly using the former instead of the latter. A nation might be inhabited by one or more cultural groups, becoming a carrier of more than one culture. The culture, or cultures, that exist within the boundaries of a nation - state certainly influence the regulations that a nation develops, but the term culture is not synonymous with nation. ${ }^{2}$

But what is culture? This is not a simple question, and never has been. Efforts have been made by anthropologists to agree on a single and unique definition on "culture", but it seemed impossible to be achieved. In 1957 Lado $^{3}$ defined culture as "the ways of people", while anthropologists refer to it as the whole way of life of a people or group. In this context, culture includes all the social practices that bond a group of people together and distinguish them from others'. ${ }^{4}$

According to UNESCO culture is that set of distinctive spiritual, material, intellectual and emotional features of a society or social group, encompassing all the ways of being in that society; at a minimum, including art and literature, lifestyles, ways of living together, value systems, traditions, and beliefs. Each culture is the sum of assumptions and practices shared by members of a group distinguishing them from other groups, and so one culture comes into clearest focus when compared to another culture maintaining different practices. However, cultures are themselves multiple, so that to insiders, every group reveals itself not as homogeneous but rather a nested series of progressively smaller groups whose members are all too aware of distinctions between themselves. Cultures themselves are seldom the focus of attention in discussion of intercultural competences, for cultures have no existence apart from the people who construct and animate them. Thus members of cultural groups more adequately serve as the focus of attention. ${ }^{5}$

\section{Why teach culture in a foreign language class?}

Culture is evident in every aspect of our daily life, as it is intertwined in all actions we undertake, no matter how unimportant they might be. We express culture when we meet and greet people, we express culture when eat and offer someone a meal, even when we make or receive a gift we express our culture. We sometimes may reflect and express our culture in and through our gestures and communication without even being aware of it. Thus children who live in a monolingual community are grown to believe that the values and way of behaving they have been taught consciously or unconsciously throughout their life are the standard ones and may remain perplexed when faced with members of other cultures who behave and act according to their values, traditions and customs. As Kramsch states "a foreign culture and one's owns culture should be placed together in order for learners to understand a foreign culture". She defines this as establishing "a sphere of interculturality". 6

Culture teaching along with language teaching is important not only to introduce students to a foreign culture and become interculturally competent, but also increase their awareness of their native culture. Vernier at al. consider it as a fifth skill along with reading, writing, speaking and listening, that "enhances student's overall learning experience". ${ }^{7}$ But, Kramsch

\footnotetext{
${ }^{1}$ Martin J, Nakayama T, Hyrje në Komunikim Ndërkulturor, MC Grow Hill, 2008: UET Press: 2010, 48.

2 Oatey S. Helen, What is Culture? - A Compilation of Quotations,

3 Lado, R. Linguistics Across Cultures; The University of Michigan Press, 1957.

${ }^{4}$ Montgomery, T, H. Reid - Thomas, Language and Social Life; The British Council, 1994, 5.

5 UNESCO, Intercultural Competences - Conceptual and Operational Framework, France, 2013, 10.

${ }^{6}$ Kramsch, C. Context and culture in language teaching. Oxford: Oxford University Press, 1993.

7Vernier, S., S. Barbuzza, S. D. Giusti, and G. D. Moral. 2008. The five language skills in the EFL classroom. Nueva Revista de Lenguas Extranjeras 10: 263-91.
} 
considers the role of culture to be more important than merely that of a fifth learning skill in language learning and teaching. She defines it as something "always in the background, right from day one". 1

By changing the "seven goals of cultural instruction" that Seelye ${ }^{2}$ provided in 1988 , Tomalin and Stempleski ${ }^{3}$ argued why culture teaching was essential in language teaching. According to them the following goals are related to culture teaching:

- To help students to develop an understanding of the fact that all people exhibit culturally-conditioned behaviours.

- To help students to develop an understanding that social variables such as age, sex, social class, and place of residence influence the ways in which people speak and behave.

- To help students to become more aware of conventional behaviour in common situations in the target culture.

- To help students to increase their awareness of the cultural connotations of words and phrases in the target language.

- To help students to develop the ability to evaluate and refine generalizations about the target culture, in terms of supporting evidence.

- To help students to develop the necessary skills to locate and organize information about the target culture.

- To stimulate students' intellectual curiosity about the target culture, and to encourage empathy towards its people.

Thus, as Tavares \& Cavalcanti ${ }^{4}$ argue, the aim of teaching culture is 'to increase students' awareness and to develop their curiosity towards the target culture and their own, helping them to make comparisons among cultures'.

\section{Conclusion}

As educators and especially as language teachers we should be aware of the difficult, but beautiful task we have when teaching a language. It is our duty to make young people aware of the importance of their culture, but also introduce them to new cultures, customs and beliefs. Make them understand the importance of culture learning and the importance of being culturally aware. We, teachers should convey the important message that all cultures are equally important and make students familiar so that they don't get lost when introduced to a new culture, or when among member of other cultures.

Teaching culture has always been an important and integral part of language teaching classes, but in Albania it has become of vital importance after the 1990's when people finally had the opportunity to travel abroad, visit and explore other countries and cultures. In order to avoid clashes amongst cultures and misunderstandings, which lead to an unsuccessful communication between people, language and culture should be taught simultaneously and in the most natural way, because the former cannot be understood without the latter.

\section{References}

Brown, H. D. (1994), Principles of language learning and teaching.

Gao, F. (2006). Language is Culture - On Intercultural Communication, Journal of Language and Linguistics, 5(1).

Kramsch, C. Context and culture in language teaching. Oxford: Oxford University Press, 1993.

Lado, R. Linguistics Across Cultures; The University of Michigan Press, 1957.

Martin J, Nakayama T, Hyrje në Komunikim Ndërkulturor, MC Grow Hill, 2008: UET Press: 2010.

Montgomery, T, H. Reid - Thomas, Language and Social Life; The British Council, 1994.

Oatey S. Helen, What is Culture? - A Compilation of Quotations.

\footnotetext{
${ }^{1}$ Kramsch, C. Context and Culture in Language Teaching. Oxford: Oxford University Press, 1993, 1.

2 Seelye. "The seven goals for cultural instruction", (1974).

3 Tomalin, B. \& Stempleski, S. Cultural Awareness. Oxford: Oxford University

Press, 1993, 7- 8 .

4 Tavares, R. \& Cavalcanti, I. Developing Cultural Awareness in EFL Classrooms. English Forum, 34:3, July-September, $1996,19$.
} 
Seelye. "The seven goals for cultural instruction", (1974).

Tavares, R. \& Cavalcanti, I. Developing Cultural Awareness in EFL Classrooms. English Forum, 34:3, July-September, 1996.

Tomalin, B. \& Stempleski, S. Cultural Awareness. Oxford: Oxford University Press,1993.

Vernier, S., S. Barbuzza, S. D. Giusti, and G. D. Moral. 2008. The five language skills in the EFL classroom. Nueva Revista de Lenguas Extranjeras 10.

Wei, Y. (2005). Integrating Chinese Culture with TEFL in Chinese Classroom. Sino-US English Teaching, 2(7). 